\title{
COVID-19: implications of SARS-CoV-2 in Colombia
}

\section{Alexander Almeida-Espinosa ${ }^{1 *}$ and Jorge A. Sarmiento-Ardila ${ }^{2}$}

'Universidad Industrial de Santander, Faculty of Public Health, Santander, Spain; ${ }^{2}$ Universidad Autónoma de Bucaramanga, Faculty of Medicine, Santander, Colombia

\begin{abstract}
COVID-19 arrived to Latin America early in March 2020. Currently, strategies are being developed in Colombia focusing on the quarantine and social and economic capital reactivation, whereby the expected results are not being obtained. In this article, we propose to review scientific evidence-based literature where information on the operation and adaptation of health systems, and social, economic and solidarity sectors of Colombia is presented. The purpose is to identify COVID-19 implications in the network that provides health services, quality of life and health-disease prognosis in the country, which is not prepared to face crises of social nature and of health systems, as well as the economic and solidarity impacts that are brought about by pandemics and crude episodes of disease.
\end{abstract}

KEY WORDS: Covid-19. Coronavirus. Pandemics. Healthcare system. Public health. Socioeconomic impact.

\section{COVID-19: implications of SARS-CoV-2 in Colombia}

\section{Resumen}

COVID-19 llegó a Latinoamérica a principios de marzo de 2020. Actualmente, en Colombia se desarrollan estrategias enfocadas en la cuarentena y la reactivación del capital social y económico, con las cuales no se están obteniendo los resultados esperados. En este artículo se propone revisar literatura basada en evidencia científica en la que se exponga información del funcionamiento y adaptación de los sistemas de salud, sectores sociales, económicos y solidarios de Colombia. El objetivo es identificar las implicaciones de COVID-19 en la red prestadora de servicios de salud, calidad de vida, pronóstico de salud-enfermedad en el país, el cual no está preparado para afrontar crisis de orden social, de sistemas de salud e impactos económicos y solidarios que conllevan las pandemias y episodios graves de enfermedad.

PALABRAS CLAVE: Covid-19. Coronavirus. Pandemias. Sistema de Salud. Salud pública. Impacto socioeconómico.

\section{Introduction}

SARS-CoV-2 arrived to Latin America in February of current year; since then, it has generated uncertainty in economic, social, health and financial aspects and, in general, in the development of the countries of the area, which are not prepared for updating their processes and strategies and rearranging the common everyday development dynamics of national systems in the face of the health-disease complexity and magnitude situation represented by the COVID-10 pandemic.
Correspondence:

*Alexander Almeida-Espinosa

E-mail: alexanderalmeida10@gmail.com
Gac Med Mex. 2020;156:330-334

Contents available at PubMed

www.gacetamedicademexico.com 0016-3813/@ 2020 Academia Nacional de Medicina de México, A.C.. Published by Permanyer. This is an open access article under the CC BY-NC-ND license (http://creativecommons.org/licenses/by-nc-nd/4.0/). 
In Colombia, the first transmission-positive cases occurred in early March, which caused restlessness in the population and prompted the implementation of weak measures to mitigate the risk of transmission. Subsequently, the closure of borders and start of the contingency stage were established, and the first search and reaction strategies were defined to deal with the dissemination of transmission and its speed, to expand hospital capacity and establish effective and timely intervention measures to mitigate the pandemic.

\section{COVID-19 context}

The year 2019 was elapsing with complete normality, in the midst of all the daily life affairs of the world population and the overwhelming speed of the new millennium. However, in early December 2019, the first cases of a pneumonia of unknown cause emerged, with an identified origin in the city of Wuhan, in the province of Hubei, China. ${ }^{1,2}$ These first cases had a common history of exposure to an outdoor food market where seafood, fish and live wildlife are sold.

On December 31, the health authorities of the People's Republic of China reported on a cluster of 27 cases of the aforementioned pneumonia, with onset of symptoms on December 8, 2019. On January 3, 2020, 44 patients with said pneumonia were reported, 11 of them with severe disease and 33 in stable conditions. It was until January 7 when the Health and Sanitation Commission identified the causative agent of this public health alert: it was a virus of the Coronaviridae family, which they named "new coronavirus", currently called SARS-CoV-2. ${ }^{3}$ All Wuhan-area outdoors food markets were closed for environmental monitoring and disinfection. ${ }^{4,5}$

SARS-CoV-2 belongs to an large family of viruses called coronaviruses; most of viruses can cause mild to moderate diseases of the upper and lower respiratory tract as, for example, common cold. However, in recent decades, coronaviruses with a reservoir in animals have emerged, which cause much more severe diseases and compromise the health of the population and even cause death. ${ }^{6,7}$

Coronaviruses not only cause respiratory diseases, they also affect the gastrointestinal, renal and neurological systems. ${ }^{8}$ Different genera have been identified: alpha-CoV, beta-CoV, gamma-CoV and delta-CoV. ${ }^{9,10}$ The latest outbreaks of this type of virus have occurred in this century: in 2002-2003, severe acute respiratory syndrome coronavirus (SARS-CoV) appeared, a
beta-CoV that arose from bats, infected 8000 people and caused around 800 deaths., 811

In 2012, mankind faced another one of these coronaviruses, MERS-CoV, which causes Middle East respiratory syndrome. It is a beta-CoV that caused 2494 confirmed infection cases and around 858 deaths in Saudi Arabia; this virus is still endemic in some areas of the East. ${ }^{12}$ The new coronavirus, SARS-CoV-2, is a beta-CoV that has very similar characteristics to SARS-CoV, with which it shares approximately $96 \%$ of nucleotides; it is believed that apart from the bat it may have an intermediate reservoir, which has thus far not been determined with certainty. ${ }^{11,13}$

\section{COVID-19 panorama in Colombia}

By May 14, 2020, the presence of SARS-CoV-2 in Colombia was summarized in 12,930 confirmed cases, out of which 7293 were males and 5637 were females. In addition, 8449 individuals showing symptoms (4903 men and 3546 women) were at home, 509 had died (312 males and 197 females), 698 were hospitalized (439 males and 259 females), 131 remained in the intensive care unit $(90$ men and 41 women), 3133 people had recovered (1542 males and 1591 females) and in 10 people (seven men and three women) no further information was available due to the loss of data.

On the other hand, most cases occurred in Bogota ( $n=4685$ ), the country's capital, which was followed by Valle del Cauca $(n=1393)$, Meta $(n=938)$, Cartagena $(n=874)$, Amazonas $(n=871)$, Atlántico $(n=641)$ and Antioquia $(n=491)$. The most affected age groups were those corresponding to the range of 20 to 40 years, with 5376 people. Six percent of cases (840 people) were imported, $30 \%(n=3859)$ were related to import, and in $64 \%(n=8231)$, the possible type of transmission was being investigated.

\section{COVID-19 impact in Colombia}

Colombia is a developing country with some actions focused on continuous improvement, ${ }^{14}$ on promoting favorable life conditions, specific production mechanisms, export of products and other actions, which has difficulties in social security, education, citizenship culture, public services and formal work, ${ }^{15}$ which are areas that have been gradually affected as COVID-19 spreads throughout the country and negatively impacts on the Colombian population health. ${ }^{16}$ 
For some authors, the health and social security system in Colombia is the service with the greatest impact, since transmission chains are being rapidly generated, ${ }^{17}$ given that clear contingency mechanisms and measurable epidemiological surveillance protocols that prevent the spread of the disease at a continuous rate in the vulnerable population have not been established. ${ }^{18}$

The second development system with the greatest impact is the economic sector, mainly the labor sector. ${ }^{19}$ The jobs of many Colombians are being canceled or suspended and wages are not being generated to meet the needs of livelihood or to protect the assets of families. ${ }^{20}$

The social context has been equally affected at the individual level, by limiting personal and interpersonal relationships, ${ }^{21}$ which generally were focused on quality of life. In addition, mental health acquires great relevance when episodes of depression, ${ }^{22,23}$ disagreement about the adoption of social isolation measures in people, and even of aggressiveness and rejection are observed. ${ }^{24}$

Finally, the return to functional normality in Colombia appears distant. It is claimed that there will be days in which productive activities will be carried out, where the worker will be directly involved and productive chains will be activated at each region of the country, with the necessary biosafety measures. ${ }^{25}$

\section{Discussion: COVID-19 in Colombia}

In Colombia, the health system is one of the most vulnerable and negatively affected sectors, due to the absence of clear and significant working ideas, ${ }^{26}$ of measures and resources for personal protection; ${ }^{27}$ as well as to insufficient or lack of intensive care units, materials and equipment and, most importantly, of trained, oriented and satisfied human resources who are committed with an effective solution of the contingency the country is being faced with. ${ }^{28,29}$

On the other hand, the number of infected patients in the country continues to increase. Mitigation and contingency measures have not resulted in a satisfactory, significant and constant reduction in the rate of infection. ${ }^{19}$ Diagnostic tests are deficient in quality and quantity, ${ }^{30}$ the hospital network is worn out ${ }^{31}$ and epidemiological measures are neither clear nor mandatory, which is added to the lack of citizenship culture and non-compliance with the rules and instructions by citizens. ${ }^{32,33}$ This has favored the growing number of patients and, therefore, difficulties in health care, which unveil the precariousness of the country's health and social security system. ${ }^{34}$

Furthermore, the support of entities such as occupational risk insurers, health institutions' managements, municipal and departmental health secretariats, of the ministry of health and health superintendence is scarce and not very strategic; it does not focus on personal protection measures for human health resources, ${ }^{35,36}$ on the treatment of clinical symptoms that warrant timely, relevant and safe intervention, or on the strengthening of the health system. ${ }^{37}$

\section{Final considerations}

The COVID-19 pandemic has generated the reprocessing of all population-based basic systems functioning, loss of human lives, instability of the health system, ${ }^{38}$ inconveniences in the provision of services, economic stagnation, cancellation of business ideas, episodes of financial bankruptcy, a collapse in mental-social health, ${ }^{39}$ dissatisfaction with the provision of services, inequity, poor government support and scarcity of options for reactivation and economic growth. ${ }^{40}$

Developing countries are not prepared to adjust their strategies in the face of an epidemic that has managed to curb the foundation and idea of growth of a nation, ${ }^{41}$ which has generated uneasiness, dissatisfaction, loss of strategic and health capacities, ${ }^{42}$ which convey negative messages to a population that tries to compensate them with the few resources the political and economic sectors grant them at the regional and national level. ${ }^{43}$

The Colombian health system is affected, and it is evident that it lacks the capacity to adapt and respond to care necessities other than those of intervention and treatment in normal contexts, ${ }^{44}$ which is due to the fact that installed capacity is inadequate and deficient. Health personnel dissatisfaction for the salary they receive, for the unsafe conditions they work in, for the lack of recognition, for the ineffectiveness of the institutional system and for the rejection by the rest of the population is evident. ${ }^{45}$

In the framework of the socioeconomic dimension, the country is experiencing a difficult situation. ${ }^{46}$ The social sphere is highly impacted, since people are not having clear personal relationships based on traditional behavior, which promotes the appearance of mood disorders that affect the integrity of the individual and his/her family nucleus. ${ }^{47}$ 
The economic sector is badly hurt. Although the quarantine favored the strengthening of telework lines ${ }^{48,49}$ in some processes, numerous jobs were put on hold or canceled, which has contributed to purchasing power loss and to a decrease in people's income.

\section{Conflict of interests}

The authors declare that they have no conflicts of interest.

\section{Funding}

The authors did not receive any sponsoring for carrying out this article.

\section{Ethical disclosure}

Protection of people and animals The authors declare that no experiments were performed on humans or animals for this research.

Confidentiality of data The authors declare that no patient data appear in this article.

Right to privacy and informed consent The authors declare that no patient data appear in this article.

\section{References}

1. Guan W, Ni Z, Hu Y, Liang W, Ou C, He J, et al. Clinical characteristics of coronavirus disease 2019 in China. N Engl J Med. 2020.

2. Jacobsen KH. Will COVID-19 generate global preparedness? Lancet. 2020;395:1013-1014.

3. Rodríguez-Morales AJ, MacGregor K, Kanagarajah S, Patel D, Schlagenhauf P. Going global - Travel and the 2019 novel coronavirus. Travel Med Infect Dis. 2020;33:101578

4. Sánchez-Duque JA, Arce-Villalobos LR, Rodríguez-Morales AJ. Enfermedad por coronavirus 2019 (COVID-19) en América Latina: papel de la atención primaria en la preparación y respuesta. Aten Primaria. 2020;52.369-372

5. Xie X, Zhong Z, Zhao W, Zheng C, Wang F, Liu J. Chest CT for typical 2019- nCoV pneumonia relationship to negative RT-PCR testing. Radiology. 2020;200343.

6. Rosa-Ramos JG, da Hora-Passos R, Brito-Teixeira M, Nunes-Gobatto L, Dos Santos-Coutinho RV, Ribeiro-Caldas JR, et al. Prognostic ability of quick-SOFA across different age groups of patients with suspected infection outside the intensive care unit: A cohort study. J Crit Care. 2018:47:178-184

7. Chen N, Zhou M, Dong X, Qu J, Gong F, Han Y, et al. Epidemiological and clinical characteristics of 99 cases of 2019 novel coronavirus pneumonia in Wuhan, China: A descriptive study. Lancet. 2020;395(10223):507-513.

8. Zhang J, Liu J, Li N, Liu Y, Ye R, Qin X, et al. Serological detection of 2019- nCoV respond to the epidemic: A useful complement to nucleic acid testing. medRxiv. 2020.

9. Ou X, Liu Y, Lei X, Li P, Mi D, Ren L, et al. Characterization of spike glycoprotein of SARS-CoV-2 on virus entry and its immune cross-reactivity with SARS-CoV. Nat Commun. 2020;11:1620.

10. Ledermann W. El hombre y sus epidemias a través de la historia. Rev Chil Infect. 2003:13:184-189.

11. Ramphul K, Mejias SG. Coronavirus disease: A review of a new threat to public health. Cureus. 2020;12:e7276.

12. Dunlop C, Howe A, Li D, Allen LN. The coronavirus outbreak: The central role of primary care in emergency preparedness and response. BJGP Open. 2020;5:bjgpopen20X101041
13. Yoon SH, Lee KH, Kim JY, Lee YK, Ko H, Kim KH, et al. Chest radiographic and CT findings of the 2019 novel coronavirus disease (COVID-19): Analysis of nine patients treated in Korea. Korean J Radiol. 2020;21:494-500.

14. Li T. Diagnosis and clinical management of severe acute respiratory syndrome coronavirus 2 (SARS-CoV-2) infection: An operational recommendation of Peking Union Medical College Hospital (V2.0). Emerg Microbes Infect. 2020;9:582-585.

15. Park JS, Lee EH, Park NR, Choi YH. Mental health of nurses working at a government-designated hospital during a MERS-CoV outbreak: A cross-sectional study. Arch Psychiatr Nurs. 2018;32:2-6.

16. Millán-Oñate J, Rodríguez-Morales AJ, Camacho-Moreno G, Mendoza-Ramírez H, Rodríguez-Sabogal IA, Álvarez-Moreno C. A new emerging zoonotic virus of concern: The 2019 novel coronavirus (COVID-19). Infectio. 2020;24:187-192.

17. Bastola A, Sah R, Rodríguez-Morales AJ, Lal BK, Jha R, Ojha HC, et al. The first 2019 novel coronavirus case in Nepal. Lancet Infect Dis. 2020;20:279-280.

18. Arteaga-Livias FK, Rodríguez-Morales AJ. La comunicación científica y el acceso abierto en la contención de enfermedades: el caso del coronavirus novel 2019 (2019-nCoV). Rev Peru Investig Salud. 2020;4:7-8.

19. Dong $\mathrm{E}, \mathrm{Du} \mathrm{H}$, Gardner L. An interactive web-based dashboard to track COVID-19 in real time. Lancet Infect Dis. 2020;20:533.534.

20. Corman VM, Landt O, Kaiser M, Meijer A, Bleicker T, Schneider J, et al. Detection of 2019 novel coronavirus (COVID-19) by real-time RTPCR. Euro Surveill. 2020,25:2000045.

21. Rueda, J.D., Rosselli, D., Ruiz-Peláez, J.G. Cost-effectiveness of prophylaxis respiratory syncytial virus infection (RSV) with palivizumab in preterm infants in Colombia. Coyuntura Económica: Investigación Económica y Social. 2013.16:137-152.

22. Pedraza-Bernal AM, Rodríguez-Martínez CE, Acuña-Cordero R. 2016. Predictors of severe disease in a hospitalized population of children with acute viral lower respiratory tract infections. J Med Virol. 2016:88:754-759.

23. Darnell MER, Subbarao K, Feinstone SM, Taylor DR. Inactivation of the coronavirus that induces severe acute respiratory syndrome, SARS-CoV. J Virol Methods. 2004:121:85-91.

24. Ruan Q, Yang K, Wang W, Jiang L, Song J. Clinical predictors of mortality due to COVID-19 based on an analysis of data of 150 patients from Wuhan, China. Intensive Care Med. 2020;46:846-848.

25. Dhama K, Sharun K, Tiwari R, Dadar M, Malik YS, Singh KP, et al. COVID-19, an emerging coronavirus infection: advances and prospects in designing and developing vaccines, immunotherapeutics, and therapeutics. Hum Vaccin Imunother. 2020:1-7.

26. Modjarrad K, Giersing B, Kaslow DC, Smith PG, Moorthy VS, WHO RSV Vaccine Consultation Expert Group. WHO consultation on respiratory syncytial virus vaccine development report from a World Health Organization meeting held on 23-24 March 2015. Vaccine. 2016;34:190-197.

27. Holmes KV, Lai MC. Coronaviridae and their replication. In: Fields B, Knipe D, Howley P editors. Fields virology. USA: Lippincot-Raven; 1996.

28. Cyranosky D, Abbott A. Virus detectives seek sources of SARS in China's wild animals. Nature. 2003;423:467.

29. Villamil-Gómez WE, Sánchez A, Gelis L, Silvera LA, Barbosa J, Otero-Nader O, et al. Fatal human coronavirus 229E (HCoV 229E) and RSV-related pneumonia in an AIDS patient from Colombia. Travel Med Infect Dis. 2020:101573.

30. Barbosa-Ramírez J, Pulido-Domínguez P, Rey-Benito G, Méndez-Rico J, Castellanos J, Páez-Martínez A. Human respiratory syncytial virus and metapneumovirus in patients with acute respiratory infection in Colombia, 2000-2011. Rev Panam Salud Publica. 2014;36:101-109.

31. Ksiazek T, Erdman D, Goldsmith CS, Zaki SR, Peret T, Emery S, et al. A novel coronavirus associated with severe acute respiratory syndrome. N Engl J Med. 2003;348:1953-1966.

32. García C. Síndrome respiratorio agudo severo (SRAS). Rev Med Hered. 2003:14.

33. Bonilla-Aldana DK, Villamil-Gómez WE, Rabaan AA, Rodríguez-Morales AJ. Una nueva zoonosis viral de preocupación global: COVID-19, enfermedad por coronavirus 2019. Iatreia 2020:33 (2) Feb 22.

34. Booth C, Matukas L, Tomlinson GA, Rachlis AR, Rose DB, Dwosh HA, et al. Clinical features of short-term outcome of 144 patients with SARS in the greater Toronto area. JAMA. 2003:289:2801-2805.

35. Koren G, King S, Knowles S, Philips E. Ribavirina in the treatment of SARS: a new trick for an old drug. CMAJ. 2003;168:1289-1292.

36. Oba Y. The use of corticosteroids in SARS. N Engl J Med. 2003;348:2034-2035.

37. Bonilla-Aldana DK, Quintero-Rada K, Montoya-Posada JP, Ramírez S, Paniz-Mondolfi A, Rabaan A, et al. SARS-CoV, MERS-CoV and now the 2019-novel CoV: Have we investigated enough about coronaviruses? - A bibliometric analysis. Travel Med Infect Dis. 2020;33:101566.

38. Wang D, Hu B, Hu C, Zhu F, Liu X, Wang B, et al. Clinical characteristics of 138 hospitalized patients with 2019 novel coronavirus-infected pneumonia in Wuhan, China. JAMA. 2020;323:1061-1069.

39. Weber MW, Mulholland EK, Greenwood BM. Respiratory syncytial virus infection in tropical and developing countries. Trop Med Int Health. 1998;3:268-280. 
40. Almeida JD, Tyrrell DA. The morphology of three previously uncharacterized human respiratory viruses that grow in organ culture. J Gen Virol. 1967:1:175-178.

41. Sarmiento IC. Estimación de la incidencia del VSR asociado con infección respiratoria aguda en una población pediátrica del Hospital Universitario Ramón González Valencia, Departamento de Pediatría, Facultad de Medicina. Spain: Universidad Industrial de Santander; 2016.

42. Piñeros JG, Baquero H, Bastidas J, García J, Ovalle O, Patiño CM, et al. Respiratory syncytial virus infection as a cause of hospitalization in population under 1 year in Colombia. J Pediatr (Rio J). 2013;89:544-548.

43. Remolina YA, Ulloa MM, Vargas H, Díaz L, Gómez SL, Saavedra A et al. Viral infection in adults with severe acute respiratory infection in Colombia. PLoS One. 2015;10:e0143152.

44. Ministerio de Salud y Protección Social Colombia. Lineamientos para la gestión de muestras durante la pandemia del SARS- COV-2 (covid-19) en Colombia. Planeación monitoreo y evaluación de los resultados en salud pública. Colombia: Ministerio de Salud y Protección Social Colombia; 2020
45. Comisión Económica para América Latina y el Caribe. Panorama social de América Latina. Chile: Comisión Económica para América Latina y el Caribe; 2019.

46. Rodríguez-Morales A. Preparación y control de la enfermedad por coronavirus 2019 (COVID-19) en América Latina. Acta Med Peru. 2020;37:3-7.

47. Saavedra C. Consenso colombiano de atención, diagnóstico y manejo de la infección por SARS-COV-2/COVID 19 en establecimientos de atención de la salud. Recomendaciones basadas en consenso de expertos e informadas en la evidencia. Infectio. 2020;24.

48. Ministerio de Vivienda, Ciudad y Territorio de Colombia. Lineamientos a tener en cuenta para la separación, manejo, recolección en el servicio público de aseo y la gestión de los residuos sólidos en el estado de emergencia generado por el SARS-COV-2 (COVID-19). Planeación monitoreo y evaluación de los resultados en salud pública. Colombia: Ministerio de Vivienda, Ciudad y Territorio de Colombia; 2020.

49. Benavides-Serralde JA, Parra-Saavedra M Miranda J, Ramírez C, Silva JL, Sanin-Blair JE, et al. Enfermedad por coronavirus SARS-COV-2 (COVID-19) en embarazo. Colombia: Federación Colombiana de Obstetricia y Ginecología Comité de Salud Materna y Perinatal; 2020. 